\title{
Yumuşak doku tutulumu olan patellanın dev hücreli tümörü: Alternatif bir tedavi yöntemi ve literatür derlemesi
}

\author{
A patellar giant-cell tumor with soft tissue involvement: \\ an alternative treatment method and review of the literature
}

\author{
Dr. Gökay Görmeli, ${ }^{1}$ Dr. Cemile Ayşe Görmeli, ${ }^{2}$ Dr. Zeynep Maraş Özdemir, ${ }^{2}$ \\ Dr. Reşit Sevimli, ${ }^{1}$ Dr. Nusret Akpolat ${ }^{3}$ \\ IInönü Üniversitesi, Turgut Özal Tıp Merkezi, Ortopedi ve Travmatoloji Anabilim Dalı, Malatya, Türkiye \\ ¿İnönü Üniversitesi, Turgut Özal Tıp Merkezi, Radyoloji Anabilim Dalı, Malatya, Türkiye \\ ${ }^{3}$ İnönü Üniversitesi, Turgut Özal Tıp Merkezi, Patoloji Anabilim Dalı, Malatya, Türkiye
}

\begin{abstract}
$\ddot{O Z Z}$
Bu makalede tipik olmayan bir bölgede meydana gelmesi ve yumuşak doku tutulumu olması nedeni ile radyolojik ve klinik olarak benzersiz olan bir patellar dev hücreli tümör olgusu sunuldu. Yirmi dört yaşında hasta kliniğimize diz önü ağrısı ile başvurdu. Radyolojik incelemeler ve perkütan iğne biyopsisi ile patellar dev hücreli tümör tanısı konuldu. Hastada total tutulan yumuşak doku komponentlerini de içerecek şekilde patellektomi ile lezyon en-blok olarak çıkarıldı ve iki adet Aşil tendon allogreft ile ekstansör mekanizma yeniden yapılandırıldı. Cerrahi sonrası tanı histopatolojik inceleme ile doğruland. On ikinci ayda hastada nüks yoktu ve diz eklem hareket açıklığ $110^{\circ}$ fleksiyon, $30^{\circ}$ ekstansiyon idi. Lysholm diz skoru 72 idi. $90 \%$ sn. hizda izokinetik kas kuvvet testinde sağlam diz ile karşılaştırıldığında ekstansiyonda $\% 51.4$, fleksiyonda ise \%21.1 kuvvet kaybı ölçüldü. Sonuç olarak, dev hücreli tümörler yıkıcı özellikleri ve yüksek nüks oranları ile tedavi edilmesi zor tümörlerdir. Kas gücü ve eklem hareket açıklığında azalma olmasına rağmen, çalışma sonuçlarımıza göre, cerrahi tedavi yöntemimizin patellanın dev hücreli tümörlerinin tedavisinde bir alternatif olabileceğini düşünmekteyiz.
\end{abstract}

Anahtar sözcükler: Dev hücreli tümör; patella; rekonstrüksiyon.

Kemiğin dev hücreli tümörleri genellikle iyi huyludur ve sıklıkla üst ve alt ekstremite uzun kemiklerinin uç kısımlarında yerleşmeye eğilimlidir. ${ }^{[1,2]}$ Diz

\begin{abstract}
In this article, we report a case of a giant-cell tumor of the patella which occurred in an atypical location with soft tissue involvement, which makes our case clinically and radiologically unique. A 24-year-old patient was admitted to our clinic with a complaint of anterior knee pain. Radiological examination and percutaneous fine needle biopsy showed a diagnosis of giant-cell tumor of the patella. The patient underwent patellectomy with en-bloc resection of the lesion with totally involved soft tissue components and the extensor mechanism was reconstructed with two Achilles allografts. After surgery, the diagnosis was confirmed by histopathological examination. At 12 months, the patient had no recurrence with $110^{\circ}$ flexion and $30^{\circ}$ extension of the range of motion of the knee. Lysholm knee score was 72 . At $90 \%$ sec isokinetic muscle strength test, the muscle strength loss was found to be $51.1 \%$ in the extensor and $21.1 \%$ in the flexor, compared to non-involved knee. In conclusion, giant cell tumors are difficult to treat, as they are destructive lesions with high recurrence rates. Despite reduced range of motion and muscle strength, based on our study results, we believe that our surgical treatment modality may be an alternative for the treatment of patellar giant cell tumors. Keywords: Giant cell tumors; patella; reconstruction.
\end{abstract}

çevresinde sık yerleşmesine karşın patellar yerleşimli ve yumuşak doku komponentli dev hücreli tümörler literatürde oldukça nadirdir. ${ }^{[2]}$ Patella yerleşimi 

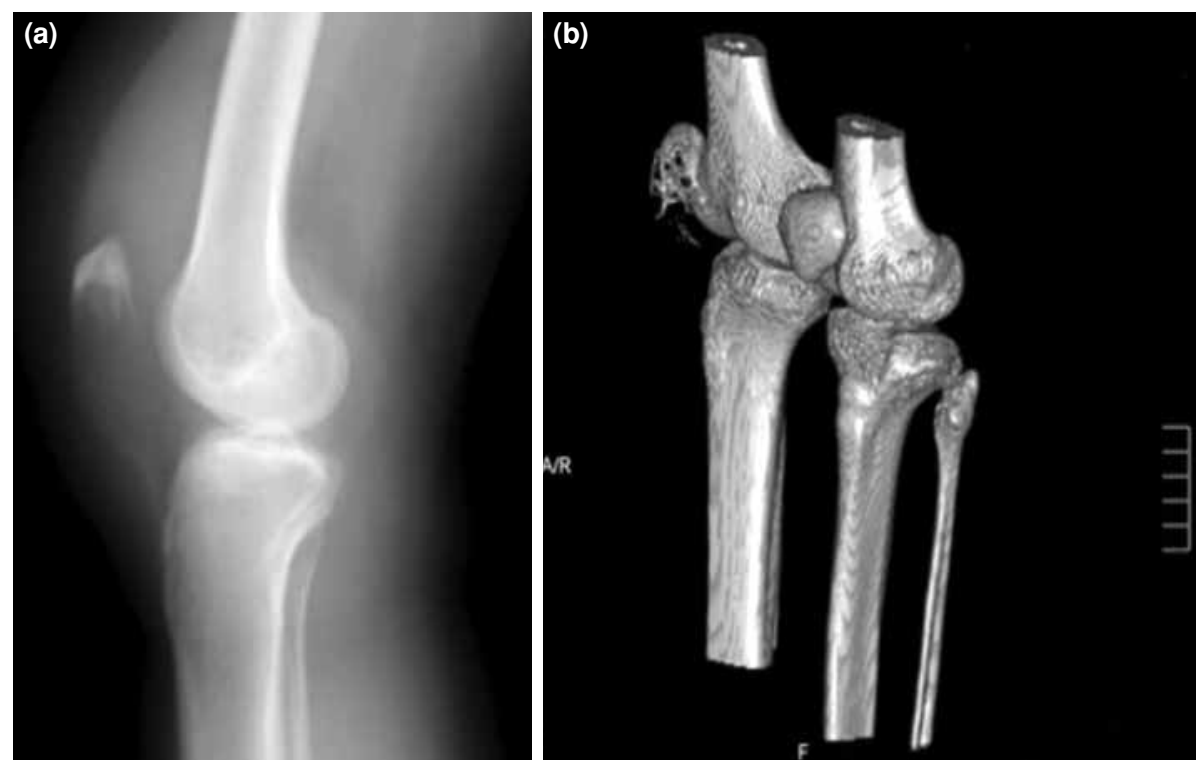

Şekil 1. Cerrahi öncesi patelladaki dev hücreli tümörün (a) direkt grafi ve (b) bilgisayarlı tomografi görüntüsü.

olan tümörlerin \%70'i iyi huylu olma eğilimindedir. ${ }^{[1,3]}$ Patellanın dev hücreli tümörleri ise iyi huylu ancak lokal agresif tümörlerdir. Yüzde 65 oranında lokal nüks ve $\% 1-2$ oranında ise akciğer metastazı görülebilmektedir. Yüzde 10 oranında ise sarkomlara dönüşebildiği saptanmıştır. ${ }^{[4]}$ Patellanın dev hücreli tümörlerinde tedavideki temel amaç nüks sıklığını en aza indirecek şekilde erken cerrahi girişim ile tümörün rezeksiyonu ve mümkün olan yeterli ve erken eklem hareket açıklığını kazanmaktır. ${ }^{[5]} \mathrm{Bu}$ yazıda patella yerleşimli, eklem içine uzanımı ve yumuşak doku tutulumu olan hastanın klinik seyri tartışıldı.

\section{OLGU SUNUMU}

Yirmi iki yaşında kadın hasta, sağ diz önünde ağrı yakınmasıyla başvurdu. Yapılan fizik muayenesinde sol diz önünde ve patella çevresindeki bölgede ağrı ve hassasiyet tespit edildi. Ek bir patoloji tespit edilmedi. Direkt grafi ve bilgisayarlı tomografi (BT)'de patella alt kutbunun tamamını tutan lobüler ve destrüktif kitle lezyonu tespit edildi (Şekil 1). Manyetik rezonans görüntüleme (MRG)'sinde; $T_{1}$ ve $T_{2}$ ağırlıklı sekanslarda heterojen hipointens kitle lezyonu ve ayrica yumuşak doku komponenti olan eklem içine uzanımlı alanlar saptandı ve ön tanı olarak yumuşak doku tutulumu olan iyi huylu patellar kemik lezyonu düşünüldü (Şekil 2). Hastanın perkütan ince iğne biyopsisi patellar dev hücreli tümör ile uyumlu idi. Bu aşamada primer hiperparatiroidiye bağlı brown tümör olasılığını ekarte etmek için serum kalsiyum, fosfor ve parathormon değerleri istendi. Sonuçların normal gelmesi ile bu seçenek ekarte edildi.
Hastanın kontrastlı toraks BT'si ve tüm vücut sintigrafisinde ek bir lezyona rastlanmadi. Daha sonra yapılan tru-cut biyopsisinde patellar dev hücreli tümör tanısı öncelikle düşünülerek lezyonun total olarak çıkarılması planlandı. Ameliyat öncesi planlamada, Campanacci ve ark.$^{[6]}$ tarafından tanımlanan radyolojik evrelemeye göre olgumuzda literatürde nadir görülen yumuşak doku tutulumu da olduğu için evre III patellar dev hücreli tümör olarak tanımlandı.

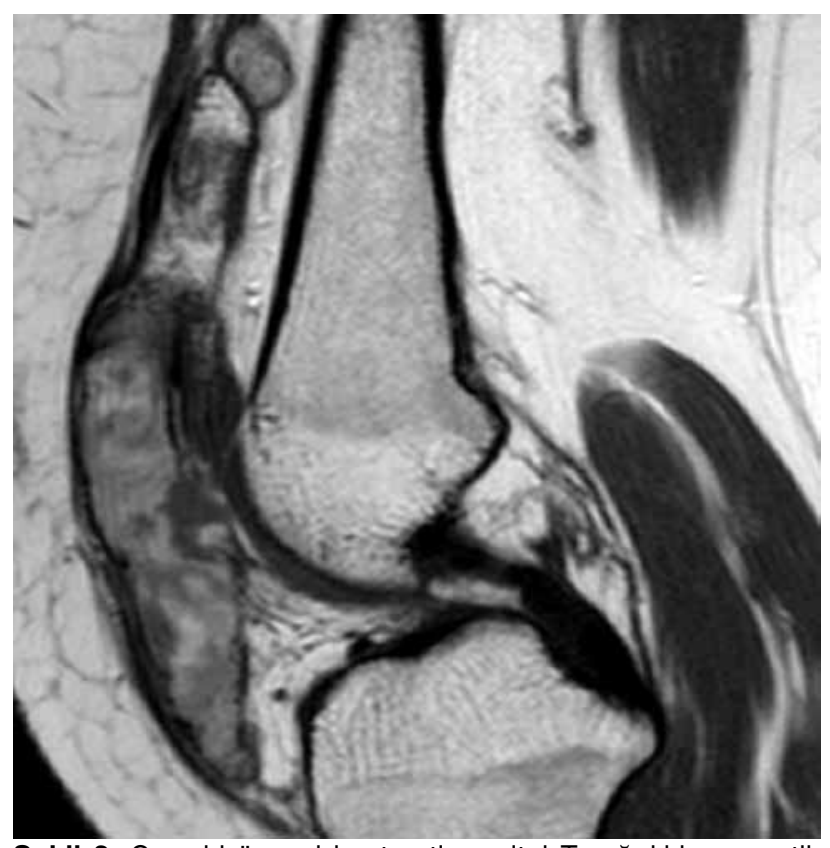

Şekil 2. Cerrahi öncesi kontrastlı sagital $T_{1}$ ağırlıklı manyetik rezonans görüntülerinde ekspansil destrüktif kemik lezyonu ve yumuşak doku uzanımı. 

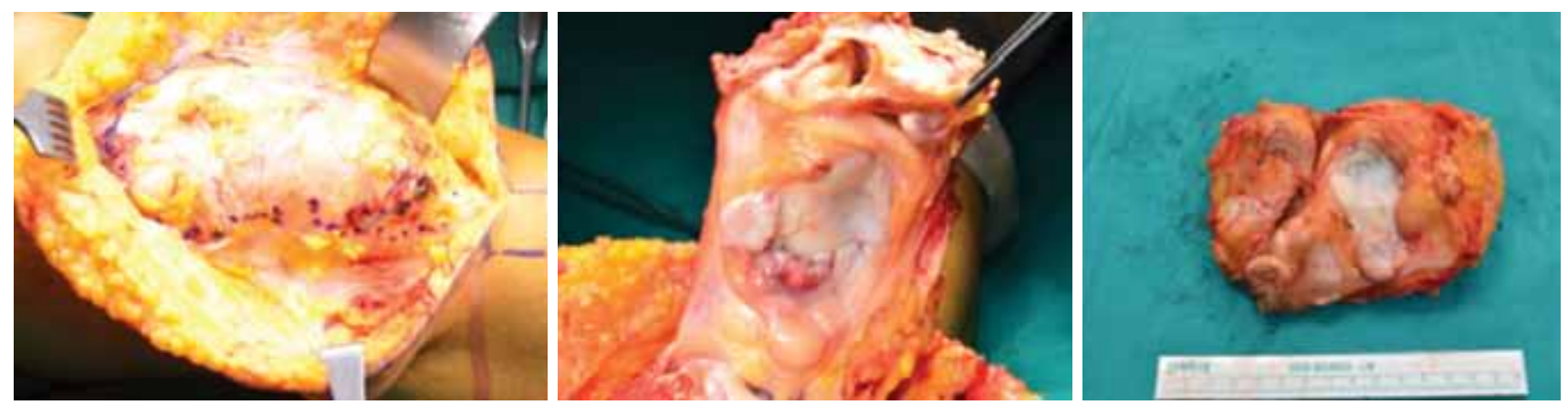

Şekil 3. Patella yerleşimli ve eklem içine uzanımı olan yumuşak doku tutulumlu patellanın dev hücreli tümörü.

Hasta yapılacak işlem konusunda bilgilendirildi ve bilgilendirilmiş hasta onamı alınarak genel anestezi altında ameliyata alındı. Sağ diz üzerinde orta hattan median parapatellar insizyonla patellaya ulaşıldı. Patellar tendon proksimal ve distalden yapışma yerlerinden ayrılarak patellayla birlikte çıkarıldı. (Şekil 3). Çıkarılan kitle patolojik incelemeye gönderildi ve yapılan frozen örneklerinde sınırların güvenli olduğu anlaşıldıktan sonra iki adet Aşil allogrefti birbiri üzerine ters çevrilerek ekstansör mekanizmanın korunması sağlanarak rekonstrüksiyon yapıldı ve distalde patellar tendonun yapışma yerine iki adet kortikal vida ile tespit edildi (Şekil 4). Patoloji sonucu dev hücreli tümör olarak bildirildi (Şekil 5, 6).

Cerrahi sonrası hasta üç hafta yük vermeden diz destek cihazı tam ekstansiyonda takip edildi. Ardından 3-6. haftalar arasında kısmi yük verilerek diz ekleminde 60 derece harekete izin verecek şekilde diz destek cihazı ile takip edildi. Bu esnada kuadriseps güçlendirme egzersizleri başlandı. Altıncı haftadan sonra diz destek cihazı sonlandırıldı ve 6-8. haftalarda 90 derece fleksiyon ve tam ekstansiyona ulaşılması amaçlandı.

Hasta ameliyat sonrası 6. hafta, 3, 6. ve 12. ayda kontrollere çağırıldı. Takiplerinde çekilen MRG'de nüks saptanmadı (Şekil 7). Metastaz olasılığı nedeni ile çekilen toraks BT'sinde de patoloji saptanmadi.
Ameliyat sonrası 12. ay kontrolünde diz ekleminde tüm yönlerdeki pasif eklem hareket açılığı tam iken; 110 derece fleksiyon ve 35 derece ekstansiyon aktif eklem hareket açıklığı vardı (Şekil 8). Hastanın ek olarak yapılan izokinetik testlerde diz fleksör/ekstansör kas gruplarının değerlendirildiği $90 \%$ sn hızlarda maksimum kuvveti diz ekstansörlerinde $25.5 \mathrm{~N} / \mathrm{M}$ ve ortalama kuvveti 20.4 Watts idi. Hastanın kas kuvveti diğer diz ile karşılaştırıldığında; ekstansiyonda \%51.4, fleksiyonda ise \%21.1 kuvvet kaybı ölçüldü. Hastanın diz fleksör/ekstansör kas kuvvet yüzdesi \%48 (N: \%65-70), Lysholm diz skoru ise 72 idi. Hastanin kontrollerinde eklem hareket açıklığında ihmal edilecek düzeyde azalma saptandı ve bunun yağlı dejenerasyona bağlı olabileceği düşünüldü.

\section{TARTIŞMA}

Patelladaki kitleler nadir olmakla birlikte patellar dev hücreli tümör daha da nadir görülmektedir. Hastalar genellikle ortopedi kliniğine birkaç aydır dizde giderek artan şişme ve ağrı yakınması ile başvurur. $^{[1-4]}$ Şişlik patellanın üst kısmından tibia tüberositasına kadar yayılabilir. Elle muayenede dizin ön yüzünde yaygın ve sabit kitle ele gelebilir. Direkt grafilerde tüm patellada kemik yıkımına neden olan lokal agresif seyirli, yayılım gösteren litik lezyon görülebilir. ${ }^{[1-4,7]}$
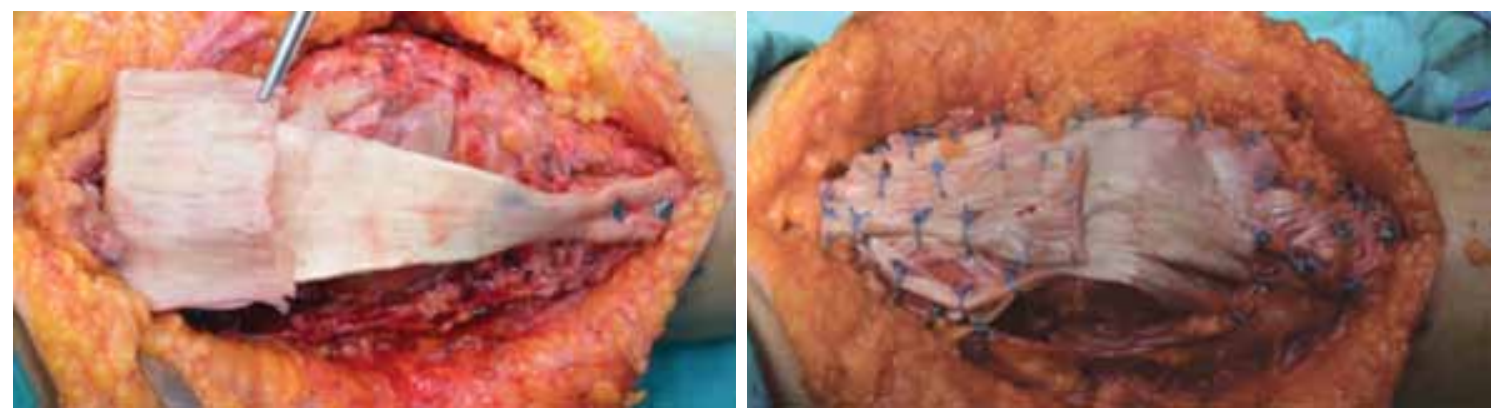

Şekil 4. Ekstansör mekanizmaya allogreft rekonstrüksiyonu uygulanması için iki adet Aşil allogrefti ile patellar tendon rekonstrüksiyonu. 


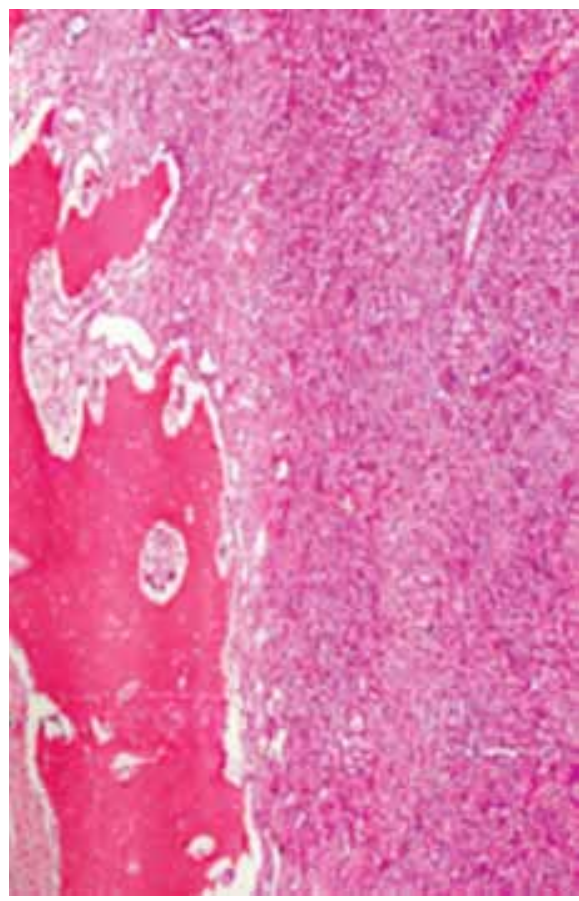

Sekil 5. Kemik dokuyu infiltre eden ve bazı kemik parçalarını çevreleyerek içine alan ve çok sayıda dev hücre izlenen fibroblastik hücre proliferasyonu görülmekte (H-E x 100).

Radyografik incelemeler sonucuna göre Campanacci ve ark.nın ${ }^{[6]}$ radyografik evrelemesi yapılarak cerrahi tedavi öncesi planlama yapılabilir. Manyetik rezonans görüntülemede patella ve patellar tendonu ilgilendiren ve kontrast tutulum gösteren kitle görüntüsü tespit edilebilir. Manyetik rezonans görüntüleri ayrıca yumuşak doku tutulumunu göstermede faydalıdır. ${ }^{[8]}$ Hiperparatiroidiye bağlı Brown

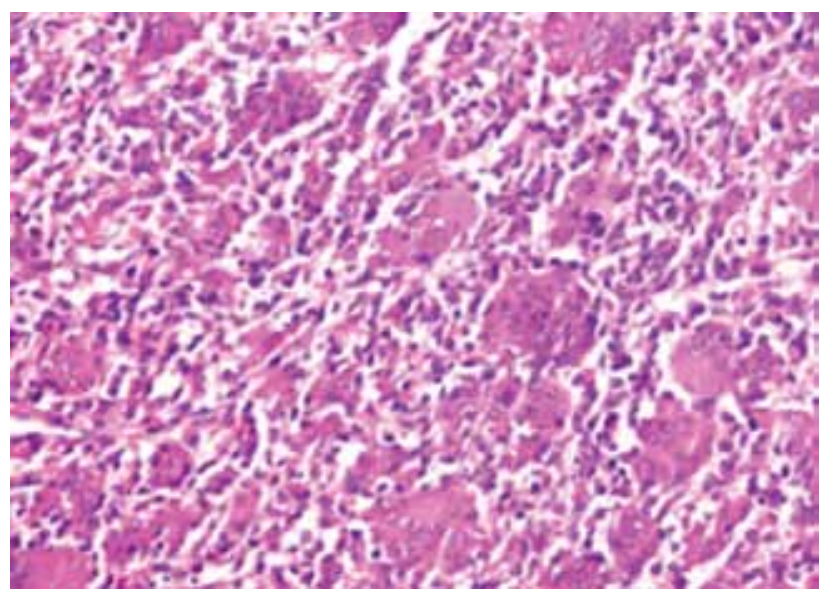

Şekil 6. Fibroselüler stroma içerisinde çok sayıda osteokalsitik dev hücre görülmekte (H-E x 200).

tümörünü elimine etmek için serum kalsiyum, fosfor ve parathormon düzeyleri istenmeli; ayrıca olgular kemik sintigrafisi ile çok odaklı tutulum açısından değerlendirilmelidir. ${ }^{[9]}$

Kesin tanı diğer tümörlerdeki gibi biyopsi ile konulur. $^{[5,10,11]}$ Biyopsi sonucuna göre Jaffe ve ark.nın ${ }^{[12]}$ tanımladığı şekilde histolojik evreleme yapılması önerilmektedir. Dev hücreli tümörler agresif seyredebilir ve akciğer metastazı yapabilir. ${ }^{[8]}$ Dolayısıyla saptand1ğında gecikmeden tedaviye başlanmalı ve kitle çıkarıldıktan sonra da sık aralıklarla kontrol edilmelidir. Literatürde çok az sayıda patellar dev hücreli olgu bildirilmiştir. ${ }^{[3,8]}$ Yayınlanmış olan bu olguların hemen hemen hepsi farklı evrelerde tümörleri içermektedir.

Tümörün evresine göre nasıl bir tedavi protokolü izlenmesi gerektiği literatürdeki tartışmalı
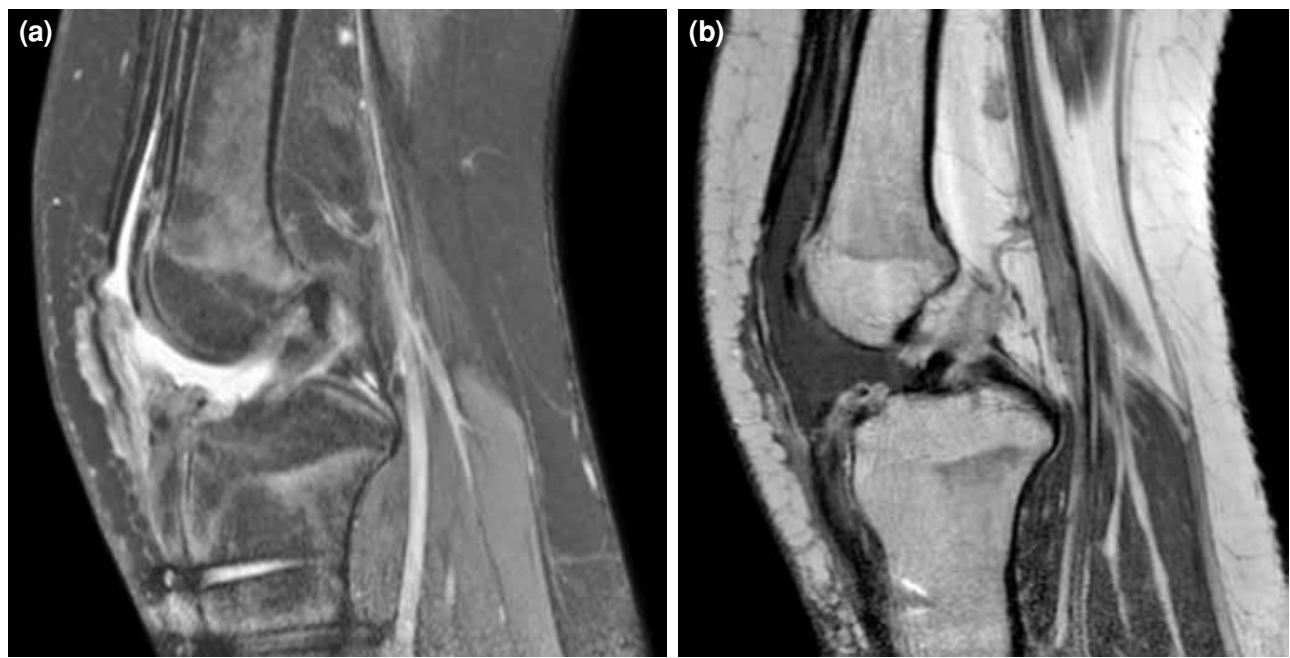

Şekil 7. Ameliyat sonrası (a) sagital proton ağırlıklı ve (b) kontrastlı $T_{1}$ ağırlıklı manyetik rezonans görüntülerinde nüks bulgusu saptanmadı. 
(a)

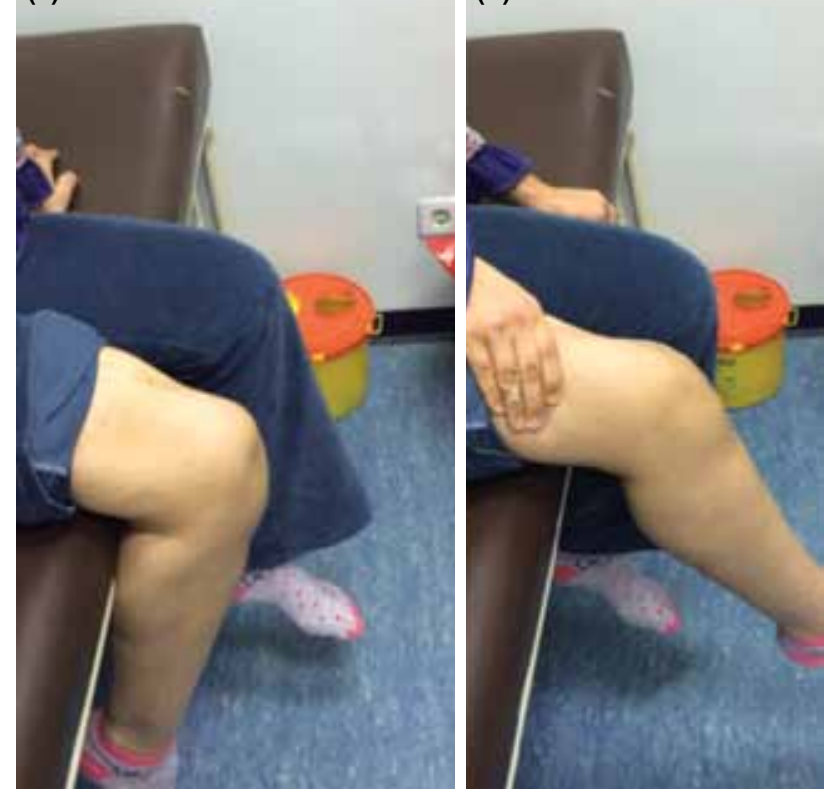

Şekil 8. Cerrahi sonrası 12. ayda hastanın aktif eklem hareket açıklığı 110 derece fleksiyon; 35 derece ekstansiyon idi.

konulardan biridir. Dev hücreli tümörlerin tedavisi çoğunlukla cerrahidir. İntralezyonel rezeksiyon ve küretaj literatürde tanımlanmıştır fakat lokal nüks ve eklem içi tümöral yayılım gibi potansiyel komplikasyonlar nedeni ile çok önerilmemektedir. ${ }^{[13]}$ Buna karşın geniş tümöral rezeksiyon uygulaması, her ne kadar lokal nüks ve eklem içi yayılmayı önlese de ekstansör mekanizmada düzeltilmesi zor bir defekt meydana getirmektedir.

Patellektomi diğer bir tedavi yöntemi olarak literatürde tanımlanmıştır. ${ }^{[14]}$ Fakat bu yöntemde de en önemli sorun, geniş rezeksiyon ve kemik kaybına bağlı olarak ekstansör mekanizmanın yeniden oluşturulamamasıdır. Literatürde, ekstansör mekanizmanın yeniden oluşturulabilmesi için farklı klinik sonuçları ile birlikte, fasiya lata strip greftleri, gastroknemius rotasyon flepleri ve serbest fasiyal greftler tanımlanmıştır. ${ }^{[15-17]}$ Fasiya lata ve gastroknemius greftleri ile verici alan morbiditesi görülmekte ve ekstansör mekanizmanın patella ile oluşan kald1raç kolu görevi tam olarak yeniden kazanılamayabilmektedir. Diz artrodezi yapılması da akla gelen bir başka tedavi seçeneği olabilir fakat ileri takip sonuçları tam olarak bilinmemektedir. ${ }^{[18]}$ Ancak literatür taramasında saptamadığımız bir yöntem olarak; patellektomi sonrası iki adet allogreftin birbiri üzerine ters çevirilerek rekonstrükte edilmesi ile ekstansör mekanizmanın kazanılması bu yöntemin alternatif bir tedavi yöntemi olarak kullanılabileceğini düşündürmektedir (Şekil 6, 7).
Cerrahi tedaviden sonraki takiplerde hastalar altıncı haftada kontrol edilmeli ve iki yıl boyunca her dört ayda bir kontrole çağırılmalıdır. Ameliyat sonrası dönemde, beşinci yıla kadar her altı ayda bir; 5 ile 10 yıl arasında ise yıllık kontrollere çağırılması önerilmektedir. Ayrıca fizik tedavi ve rehabilitasyon ile ekstansör mekanizmanın ve eklem hareket açıklığının yeniden kazanılması sağlanmalıdır. ${ }^{[19]}$

Patelladaki kitleler her ne kadar nadir görülse de patellanın dev hücreli tümörü lokal agresif seyreden ve tedavi gerektiren bir tümördür. Tedavi yöntemleri tartışmalıdır ve en önemli sorun ekstansör mekanizmanın yeniden oluşturulabilmesidir. İki adet allogreft ile geniş rezeksiyon sonrası rekonstrüksiyon; ekstansör mekanizmanın bir miktar eklem hareket açıklığı ve kas gücü kaybı olmasına rağmen hastanın günlük aktivitelerini yerine getirecek şekilde korunması, alternatif bir tedavi seçeneği olabileceğini düşündürmektedir. Ayrıca sık nüks nedeni ile hasta takibinin sık aralıklarla yapılması gerektiği unutulmamalıdır.

\section{Çıkar çakışması beyanı}

Yazarlar bu yazının hazırlanması ve yayınlanması aşamasında herhangi bir çıkar çakışması olmadığını beyan etmişlerdir.

\section{Finansman}

Yazarlar bu yazının araştırma ve yazarlık sürecinde herhangi bir finansal destek almadıklarını beyan etmişlerdir.

\section{KAYNAKLAR}

1. Ferguson PC, Griffin AM, Bell RS. Primary patellar tumors. Clin Orthop Relat Res 1997;336:199-204.

2. Kesgin E, Çelik C, Karaoğlu S. Arthroscopic resection of osteochondroma of the knee: two case reports. Eklem Hastalik Cerrahisi 2013;24:112-6.

3. Yoshida Y, Kojima T, Taniguchi M, Osaka S, Tokuhashi Y. Giant-cell tumor of the patella. Acta Med Okayama 2012;66:73-6.

4. Mercuri M, Casadei R, Ferraro A, de Cristofaro R, Balladelli A, Picci P. Tumours of the patella. Int Orthop 1991;15:115-20.

5. Wurtz D. Advances in the treatment of giant cell tumor of bone. Curr Opin Orthop 1999;10:474-80.

6. Campanacci M, Baldini N, Boriani S, Sudanese A. Giant-cell tumor of bone. J Bone Joint Surg [Am] 1987;69:106-14.

7. Saglik Y, Yildiz Y, Basarir K, Tezen E, Güner D. Tumours and tumour-like lesions of the patella: a report of eight cases. Acta Orthop Belg 2008;74:391-6.

8. Wilson JS, Genant HK, Carlsson A, Murray WR. Patellar giant cell tumor. AJR Am J Roentgenol 1976;127:856-8.

9. Escribano Rueda LC, Sánchez Gutiérrez SJ, Gómez-Rice A, de Lucas Aguilar R, Gómez García A. Patellar giant cell tumour: presentation of a case and a review of the literature. Rev Esp Cir Ortop Traumatol 2012;56:486-90. 
[Abstract]

10. Ayan I, Serinsöz E. Osteoblastoma in the os hamatum: a rare case report. [Article in Turkish] Eklem Hastalik Cerrahisi 2014;25:56-9.

11. Gökkuş K, Aydın AT, Sağtaş E. Solitary osteochondroma of ischial ramus causing sciatic nerve compression. Eklem Hastalik Cerrahisi 2013;24:49-52.

12. Jaffe HL, Lichtenstein L, Partis RB. Giant cell tumor of bone. Its pathologic appearance, grady supposed variant and treatment. Arc Pathol 1940;30:993-1031.

13. Malhotra R, Sharma L, Kumar V, Nataraj AR. Giant cell tumor of the patella and its management using a patella, patellar tendon, and tibial tubercle allograft. Knee Surg Sports Traumatol Arthrosc 2010;18:167-9.

14. Kransdorf MJ, Moser RP Jr, Vinh TN, Aoki J, Callaghan JJ. Primary tumors of the patella. A review of 42 cases. Skeletal Radiol 1989;18:365-71.
15. McDonald DJ, Sim FH, McLeod RA, Dahlin DC. Giant-cell tumor of bone. J Bone Joint Surg [Am] 1986;68:235-42.

16. Agarwal S, Jain UK, Chandra T, Bansal GJ, Mishra US. Giant-cell tumors of the patella. Orthopedics 2002;25:749-51.

17. Karahasanoğlu I, Yoloğlu O, Citlak A, Kerimoğlu S, Turhan AU. Biomechanical examination of patellar tendon ruptures repaired with a tendon graft: an experimental study. [Article in Turkish] Eklem Hastalik Cerrahisi 2014;25:47-51.

18. Balke M, Schremper L, Gebert C, Ahrens H, Streitbuerger A, Koehler G, et al. Giant cell tumor of bone: treatment and outcome of 214 cases. J Cancer Res Clin Oncol 2008;134:969-78.

19. Lackman RD, Hosalkar HS, Ogilvie CM, Torbert JT, Fox EJ. Intralesional curettage for grades II and III giant cell tumors of bone. Clin Orthop Relat Res 2005;438:123-7. 